\title{
Mineralogical and Physical Characterization of Clay of Sitakunda Anticline: Used for Ceramic Industries
}

\section{Mst. Shanjida Sultana*, Mohammad Nazim Zaman, Md. Aminur Rahman, Pradip Kumar Biswas, Pranab Kumar Nandy}

Institute of Mining, Mineralogy and Metallurgy, Bangladesh Council of Scientific and Industrial Research (BCSIR), Khonjonpur, Joypurhat, Bangladesh

Email: *shanjida-immm@bcsir.gov.bd

How to cite this paper: Sultana, Mst.S., Zaman, M.N., Rahman, Md.A., Biswas, P.K. and Nandy, P.K. (2018) Mineralogical and Physical Characterization of Clay of Sitakunda Anticline: Used for Ceramic Industries Journal of Minerals and Materials Characterization and Engineering, 6, 333-344.

https://doi.org/10.4236/jmmce.2018.63023

Received: March 9, 2018

Accepted: May 7, 2018

Published: May 10, 2018

Copyright $\odot 2018$ by authors and Scientific Research Publishing Inc. This work is licensed under the Creative Commons Attribution International License (CC BY 4.0).

http://creativecommons.org/licenses/by/4.0/

\begin{abstract}
This study focuses on mineralogical and chemical characterization of clay of Sitakunda anticline, Bangladesh and potential suitability of this shale as raw materials in ceramic industries. The shale which is clay in texture is composed of chlorite and kaolinite with common illite, smectite, quartz, mica and feldspar. There are two types of samples in color, grey and red. Chemical compositions of clay samples are analyzed by XRF and mineralogical composition of sample analyzed by XRD. Clay samples contain significant amount $\mathrm{SiO}_{2}, \mathrm{Al}_{2} \mathrm{O}_{3}$ and $\mathrm{Fe}_{2} \mathrm{O}_{3}$ with other minor compounds. The plasticity index (12.08 and 16.37) indicates medium ranges of the plasticity of clay. To determine the suitability of ceramic materials, samples were made in a rectangular shape for firing $850^{\circ} \mathrm{C}$ to $1100^{\circ} \mathrm{C}$ temperature. The samples were tested for different physical properties such as compressive strength, linear shrinkage, water absorption, porosity and bulk density. Low linear firing shrinkage $(0.7 \%$ to $2.69 \%$ ) and water absorption (1.5\% to $11 \%$ ) of the developed ceramic bodies were observed. Scanning Electron Microscope photographs confirm the vitrification of the ceramic bodies. The chemical, physical and ceramic properties of these clays indicate their suitability as raw materials for the production of a wide range of ceramic materials.
\end{abstract}

\section{Keywords}

Clay, Water Absorption, Linear Shrinkage, Ceramic

\section{Introduction}

Clays are the main raw materials in manufacturing various ceramic products for 
building construction. Physical, chemical and mineralogical characteristics of clay made it unique properties related to their own natural genesis. The ceramics industry relies on clays from nearby deposits; therefore, characterization and quality control of clay are important for local products [1] [2] [3] [4] [5].

Common clay minerals for traditional application are kaolinite, illite and montmorillonite. Secondary components in clays are quartz, feldspar, pyrites, iron, carbonates and other soluble salts which influence largely on clays use in specific applications [6]. The percentage of the minerals oxides $\left(\mathrm{Fe}_{2} \mathrm{O}_{3}, \mathrm{MgO}\right.$, $\mathrm{CaO}, \mathrm{Na}_{2} \mathrm{O}$ etc.) in the clay ultimately determines the areas of applications of the clay such as in bricks, floor, tiles, paper etc. and quantity of alkali metal oxides $\left(\mathrm{Na}_{2} \mathrm{O}, \mathrm{K}_{2} \mathrm{O}, \mathrm{CaO}\right.$ etc.) indicates their suitability for making ceramic products [7].

The ceramics industry is a growing manufacturing sector in Bangladesh. Ceramic tiles used as construction material and its demand are increasing day by day for architectural and construction of modern buildings. About $95 \%$ of raw materials for making quality and exportable ceramic products in Bangladesh are imported from abroad and rest raw materials collected from mainly middle part of the country [8].

Shale, collected from the hilly area, which is mainly clay in texture, may be a new source of clay materials for ceramic or other industries in Bangladesh. The main objective of this study is the best understanding of clays of Hill Tracts of Bangladesh, composition, mineralogy, texture that can be utilized in several ceramic industries.

\section{Geological Setting}

The study area is located in Barabkunda, Sitakunda hill region located in the northwestern part of Chittagong district Bangladesh (22 $\left.38^{\prime} 15^{\prime \prime} \mathrm{N}-91^{\circ} 39^{\prime} 33^{\prime \prime} \mathrm{E}\right)$ (Figure 1). Geologically the Sitakunda Hill range is an anticline, most prominent structure of the Bengal Basin. The Bengal Basin of Bangladesh includes one of the largest delta complexes in the world, is filled mainly by orogenic sediments derived from the eastern Himalayas to the north and the Indo-Burman ranges to the east [9] [10]. The Sitakunda anticline is in the western sub zone of the folded flank, the western most continuation of the Arkan-Yoma folded belt and developed from the deformation by the relative movement of the Indian plate and Burmese sub plate, since this anticline is trending in NNW-SSE direction. [11] [12] [13]. The bulk of the deltaic deposits are Miocene and younger. The sediments of the Miocene-age Surma Group, with a thickness of $4-5 \mathrm{~km}$ comprise a succession of alternating shales, siltstones, sandy shales and sandstones, with occasional conglomerates [14]. The thickness of repetitive Miocene-Pleiocene shale-sand sequence constitutes the surma group and is divided into Bhuban and Bokabil formations [9] [15]. The Bhuban Formation is composed of fine grained, well indurated, massive to thickly bedded sandstones, shales, claystones and siltstone and Bokabil Formation is composed of fine to medium grained moderately indurated sandstones with shale, silty shales and siltstones. The 


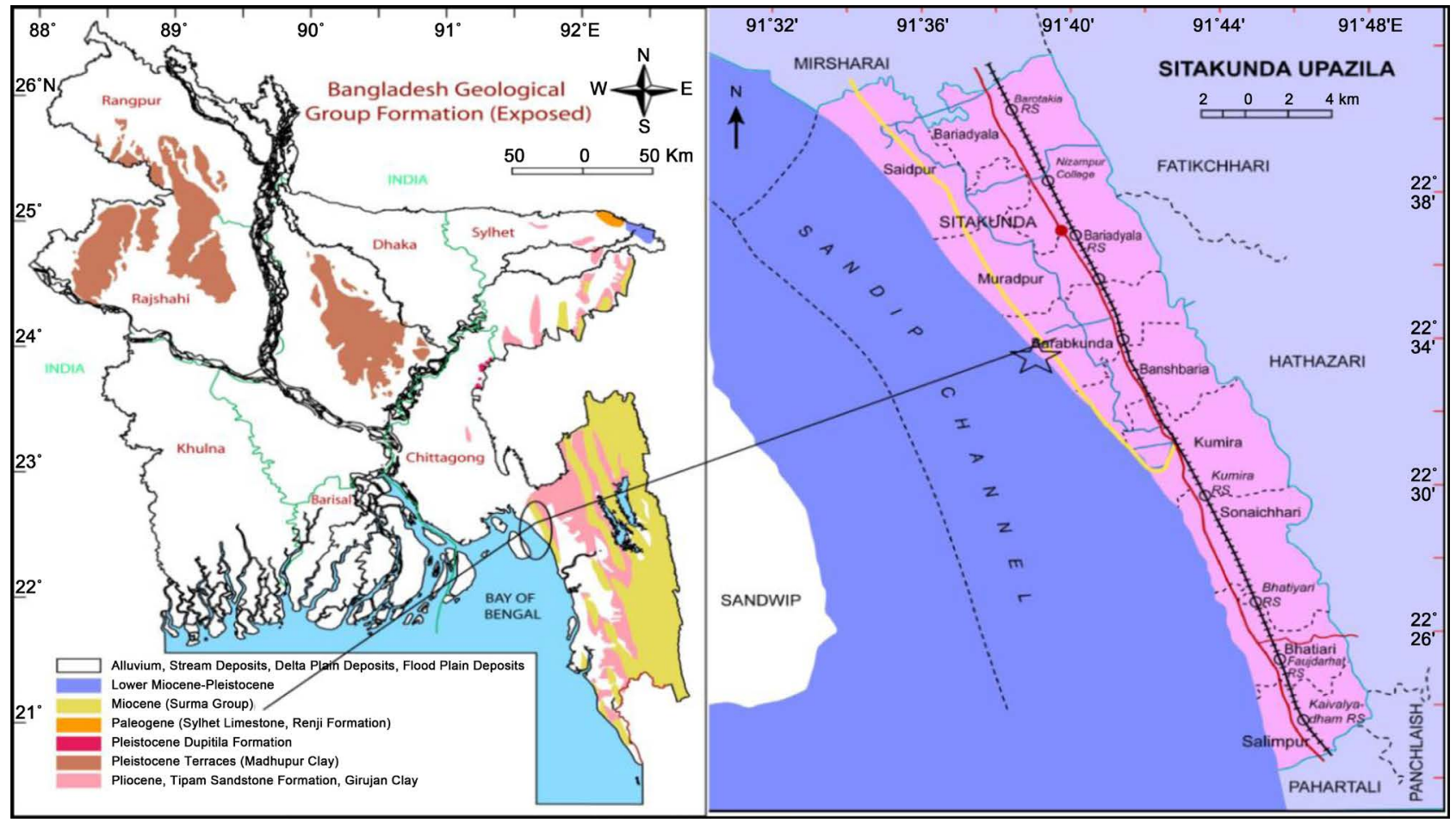

(a)

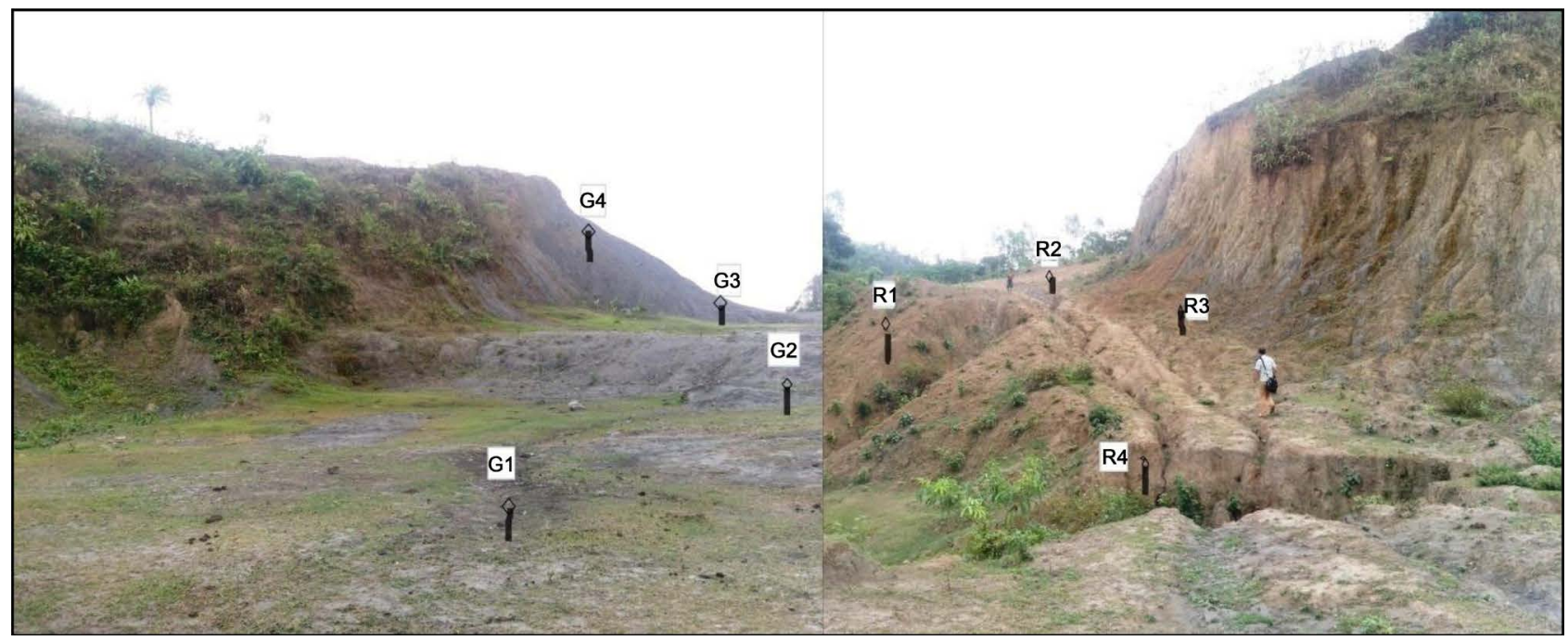

(b)

Figure 1. (a) Map of Bangladesh geological group formation (right) and map of study area (left); (b) Photograph of field area and location of collected two color clay samples (Grey-left, Red-right).

shales of mud dominated facies association are both calcareous and non-calcareous and composed of chlorite and kaolinite with common illite, smectite, quartz, mica and feldspar [16] [17].

\section{Materials and Method}

The two types of clay samples (Grey and red in color) were collected from Barabkunda, Sitakunda hill tracts area, Chittagong District (Figure 1(b)). Eight 
representatives clay samples (four in each color) were collected from the valley and hilly area of the study area. Samples were ground in powder form, dried in air dry and sieving at $250 \mu \mathrm{m}$ with sieve analyzer. Plasticity of clay sample was determined by Atterberg's method.

The oxide of elements was determined by X-ray fluorescence (XRF) Spectrometer method following the standard procedure using Rigaku ZSX Primus XRF machine equipped with an end window $4 \mathrm{~kW}$ Rh-anode X-ray tube. XRF analysis of the sample reveals that chemical composition of the samples is almost same, therefore mixed grey sample $(G)$ and red $(R)$ sample was chosen for other analysis and characterization of ceramic sample. The mineralogical analyses of samples were carried out by X-ray diffraction (XRD). The clay samples in oriented mounts run by BRUKAR X-ray diffractometer operating at $40 \mathrm{kV}$ and $40 \mathrm{~mA}$ using $\mathrm{Cu}-\mathrm{Ka} 1$ radiation $(\lambda=1,5406 \AA)$. Diffraction patterns were recorded between 5 and $70^{\circ} 2 \theta$ at a step size of $0.02^{\circ}$ and a dwell time of $0.6 \mathrm{~s}$ per step.

Then samples thoroughly mixed with water (5\% to 7\%) until approximately the optimum moisture content as determined during compaction. The test specimens were rectangular $(50 \mathrm{~mm} \times 50 \mathrm{~mm} \times 15 \mathrm{~mm})$ in size for brick, tiles or other ceramic purposes.

The specimens were air-dried at room temperature for $24 \mathrm{hr}$ and then oven dried at $110^{\circ} \mathrm{C}$ for another $24 \mathrm{hr}$ to remove water content. All samples were fired for analysis of various physical properties (bulk density, water absorption, porosity, specific gravity, linear shrinkage, strength etc) by heat treatment from $850^{\circ} \mathrm{C}$ to $1100^{\circ} \mathrm{C}$ (Figure 2), in an electric furnace for $1 \mathrm{hr}$ under a heating rate of $10^{\circ} \mathrm{C} / \mathrm{min}$. Bulk density, water absorption, porosity and specific gravity were determined by boiling water method followed by ASTM C20-00 [18]. Compressive strength was determined by using Control ADVENTEST 9 (Model 50C-6600) machine. Microstructures of the ceramic samples were observed by Scanning

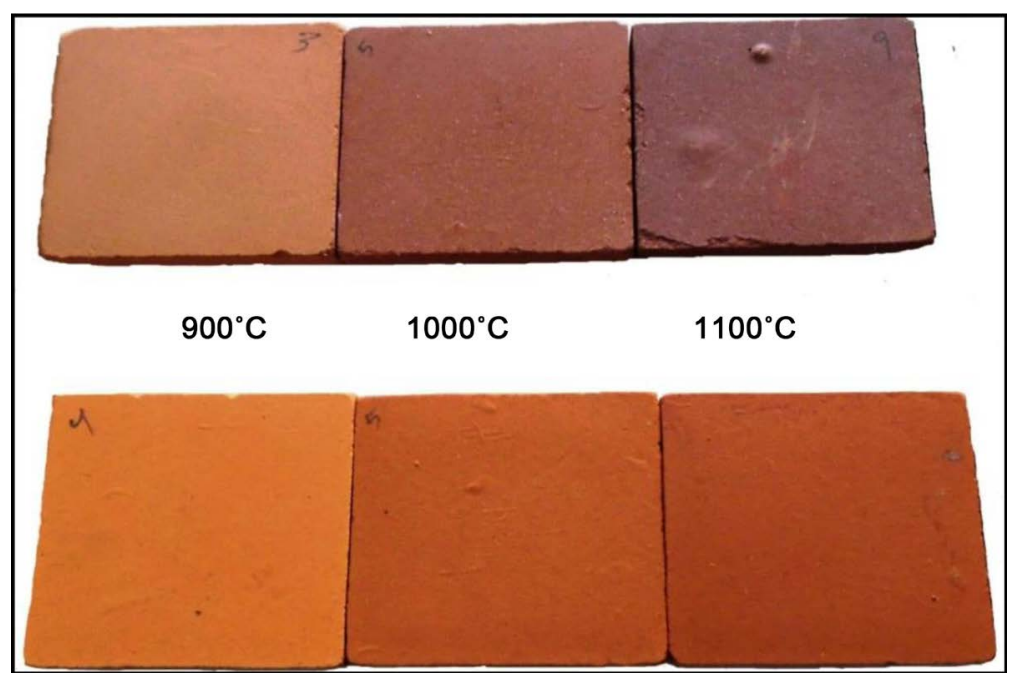

Figure 2. Ceramic samples fired at different temperatures (Sample-G at up and Sample-R at down). 
Electron microscopy (JEOL JSM 7600F).

\section{Results and Discussion}

\subsection{Mineralogical Characterization of Clay Samples}

The chemical composition of clay samples is shown in Table 1 . The result shows that clay samples comprise with $\mathrm{SiO}_{2}$ and $\mathrm{Al}_{2} \mathrm{O}_{3}$ as major oxide. Grey clay consists of $16.92 \% \mathrm{Al}_{2} \mathrm{O}_{3}, 60.68 \% \mathrm{SiO}_{2}, 8.32 \% \mathrm{Fe}_{2} \mathrm{O}_{3}$ with other minor compounds and red clay consists of $24.02 \% \mathrm{Al}_{2} \mathrm{O}_{3}, 58.89 \% \mathrm{SiO}_{2}$, and $11.27 \% \mathrm{Fe}_{2} \mathrm{O}_{3}$ with other minor compounds. The significant presence of alkaline and alkali earth oxides $\left(\mathrm{Na}_{2} \mathrm{O}, \mathrm{K}_{2} \mathrm{O}, \mathrm{CaO}\right.$ etc.) in samples will help in producing ceramic materials at lower sintering process [19].

A high percentage of $\mathrm{Fe}_{2} \mathrm{O}_{3}$ may be attributed mainly for the coloring of ceramic products, other constituents such as $\mathrm{CaO}, \mathrm{MgO}, \mathrm{Na}_{2} \mathrm{O}$ and $\mathrm{TiO}_{2}$ can appreciably modify the color of the fired clay as shown in Figure 2. The presence of large amounts of fluxes as well as $\mathrm{Fe}_{2} \mathrm{O}_{3}$ in Sitakunda shale (clay) increases the chance to form a considerable amount of liquid phase at a relatively lower firing temperature that might be helpful for ceramic industries.

The chemical composition of the samples is almost same, therefore mixed grey sample $(\mathrm{G})$ and red (R) sample was chosen for other analysis and characterization of ceramic sample. The plasticity index (12.08 and 16.37) indicates medium ranges of plasticity of clay (Figure 3) samples in Holtz and Kovacs [20] diagram. It can be observed the values of liquid limit at about $34.28 \%$ and $37.67 \%$, which is in agreement with the range defined in the literature $30 \%$ $60 \%$ ) to the composition used for ceramic production [7]. The particle size distribution analysis of the samples has been done by particle size analyzer (Figure 4) which indicates that the samples are silty clay type, suitable for ceramic production [21] [22] [23].

XRD patterns (Figure 5) reveal that the studied samples characterized with the dominance of kaolinite, illite and chlorite clay minerals. Literature [17] [24] [25] also reported about the presence of high quartz and illite-chlorite with small amount kaolinite clay minerals in this area. The large amount of $\mathrm{K}_{2} \mathrm{O}$ content in

Table 1. Chemical compositions of the clay samples (wt\%).

\begin{tabular}{ccccccccc}
\hline Clay samples & $\mathrm{SiO}_{2}$ & $\mathrm{Al}_{2} \mathrm{O}_{3}$ & $\mathrm{MgO}$ & $\mathrm{Na}_{2} \mathrm{O}$ & $\mathrm{K}_{2} \mathrm{O}$ & $\mathrm{CaO}$ & $\mathrm{Fe}_{2} \mathrm{O}_{3}$ & $\mathrm{TiO}_{2}$ \\
\hline $\mathrm{G}-1$ & 60.68 & 16.92 & 2.44 & 1.17 & 3.76 & 4.67 & 8.32 & 0.93 \\
$\mathrm{G}-2$ & 59.68 & 18.59 & 2.64 & 1.07 & 3.85 & 4.03 & 8.11 & 1.02 \\
$\mathrm{G}-3$ & 60.12 & 17.57 & 2.41 & 1.13 & 3.80 & 4.55 & 8.29 & 1.01 \\
$\mathrm{G}-4$ & 60.61 & 16.98 & 2.43 & 1.16 & 3.75 & 4.67 & 8.31 & 0.97 \\
R-1 & 58.89 & 24.02 & 0.79 & 0.18 & 2.83 & 0.13 & 11.27 & 1.03 \\
R-2 & 55.95 & 24.40 & 0.82 & 0.19 & 2.81 & 0.11 & 13.49 & 1.14 \\
R-3 & 58.01 & 23.93 & 0.81 & 0.19 & 2.83 & 0.14 & 11.94 & 1.19 \\
R-4 & 57.42 & 24.67 & 0.77 & 0.19 & 2.85 & 0.13 & 12.36 & 1.06 \\
\hline
\end{tabular}




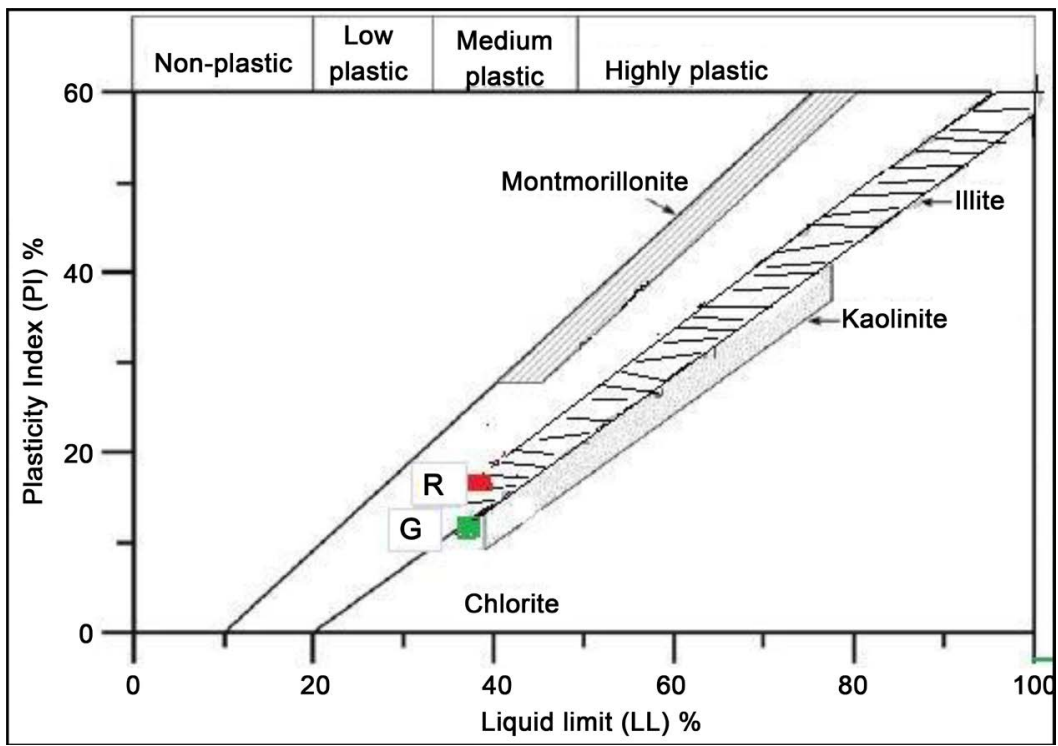

Figure 3. Position of clay samples on the Holtz and Kovacs diagram.

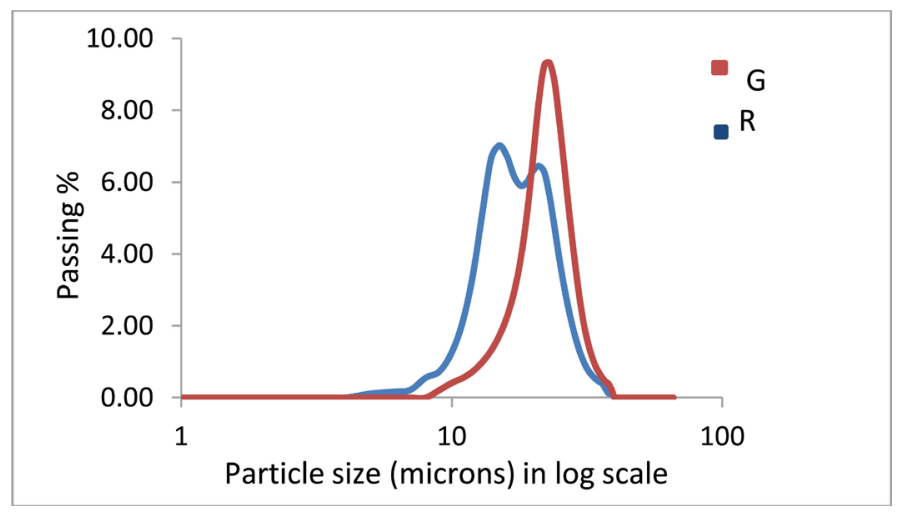

Figure 4. Particle size distribution of clay samples.

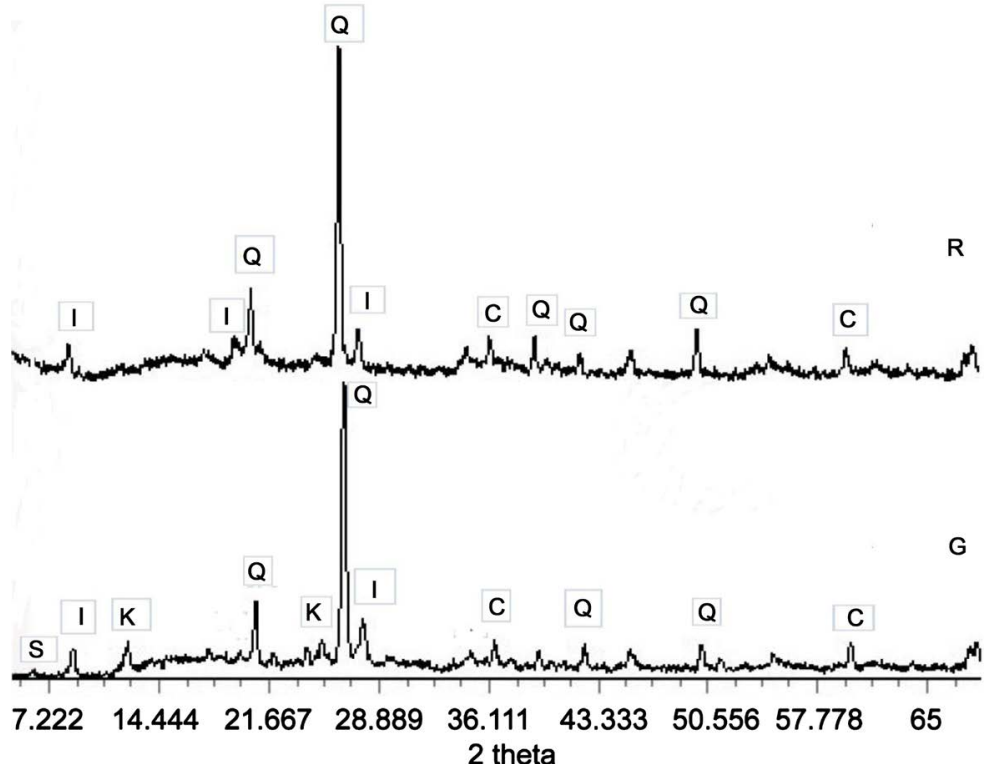

Figure 5. XRD pattern of the clay samples $(\mathrm{Q}=$ Quartz, $\mathrm{I}=$ Illite, $\mathrm{K}=$ Kaolinite, $\mathrm{C}=$ Chlorite $)$. 
clay samples reflects the abundance of illite [8] This clay shows the chemical composition, rich in silica and alumina because of the presence clay minerals and quartz, they have great influence on developing ceramic materials.

\subsection{Characterization of Prepared Samples for Use in Ceramic Industries}

To determine the quality of the ceramic tile bodies, various physical characteristics e.g. water absorption, porosity, bulk density, shrinkage were considered. The technical characteristics were measured in one representative clay mixture ( $G$ and $\mathrm{R})$.

Figure 6 shows the behavior of water absorption and firing shrinkage of the prepared ceramic bodies. Figure shows that values of linear shrinkage were increased with increasing temperature. With the increase in firing temperature, values for water absorption tend to decrease since a greater densification of the sample occurred. The water absorption of ceramic samples for sample-R was within the range of $1.5 \%$ to $6 \%$, whereas, water absorption of samples for sample-G were within the range of $6 \%$ to $11 \%$. According to ISO 13006 standards, on the basis of water absorption, ceramic tiles divided these categories which belong: $<3 \%$ (Group I), 3\% - 10\% (Group II) and >10\% (Group III). It can be seen that the bodies of sample R belong to Group I and II whereas the products of sample G belong to Group III. So, sample R (red clay) can be used for making semi-vitrified to vitrified tiles (unglazed red stoneware) and sample G (grey clay) can be used for semi vitrified to porous tiles [26].

Figure 7 shows the porosity and bulk density of the different samples. With increasing temperature, the values of porosity decreased. Generally, no significance difference observed for the values of bulk density. The results of the physical properties of ceramic samples by different firing temperature indicates that sample-R (red clay) is preferable than sample-G (grey clay) for making vitrified ceramic tiles.

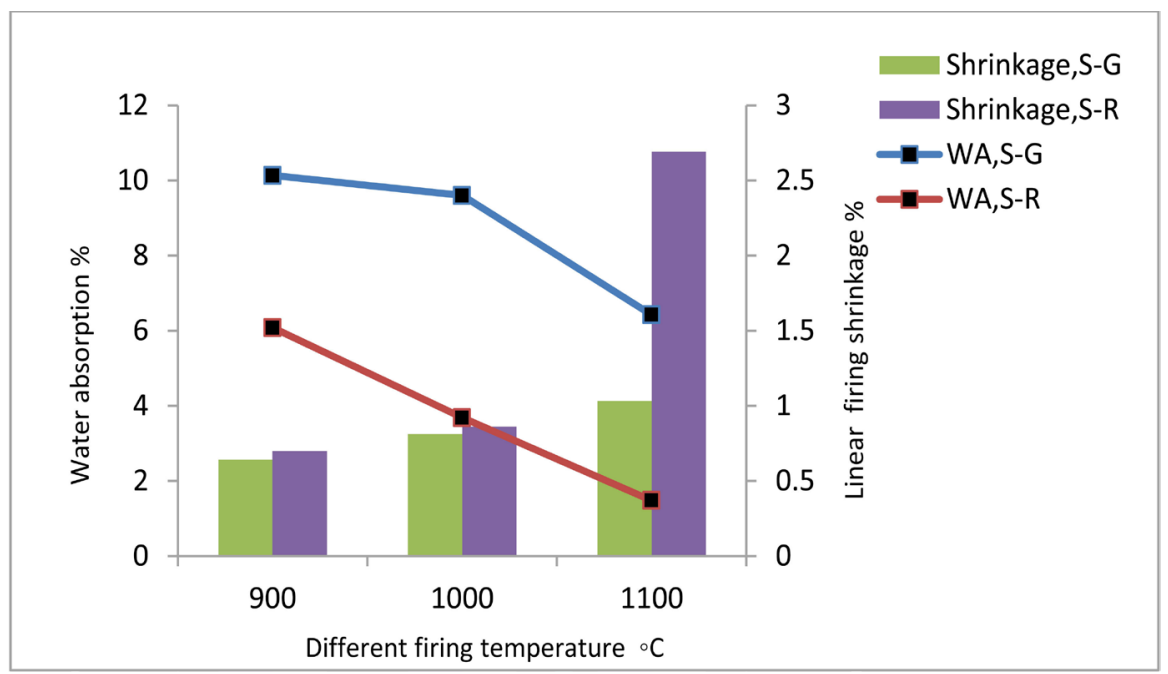

Figure 6. Variation of water absorption and shrinkage with temperature. 


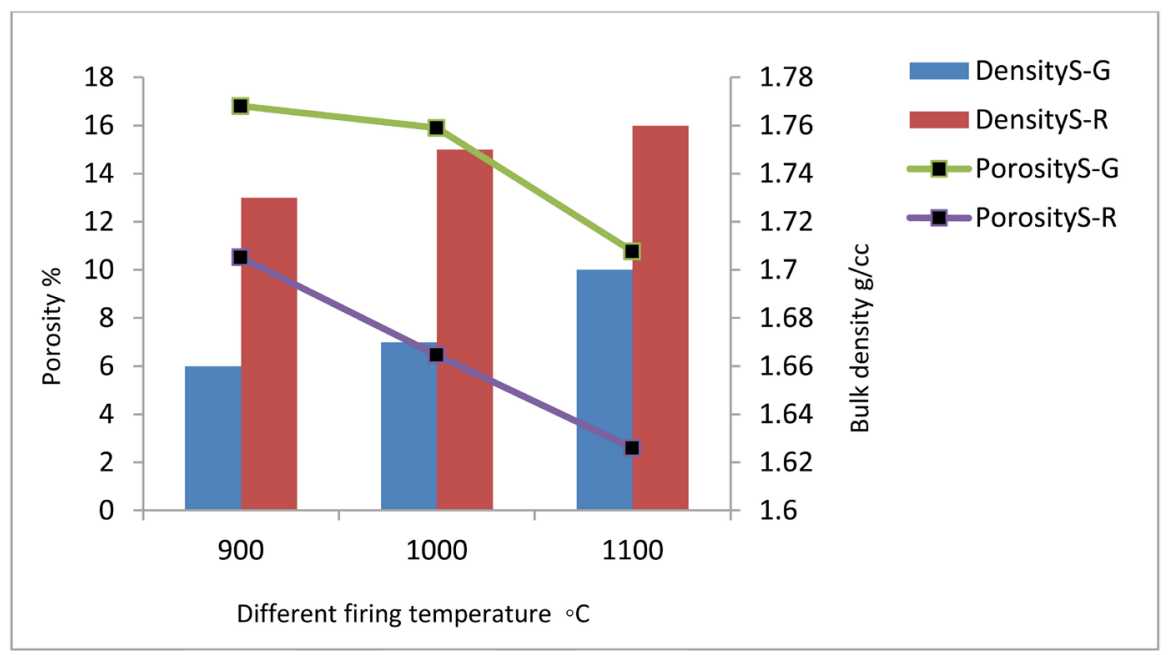

Figure 7. Variation of porosity and bulk density with temperature.

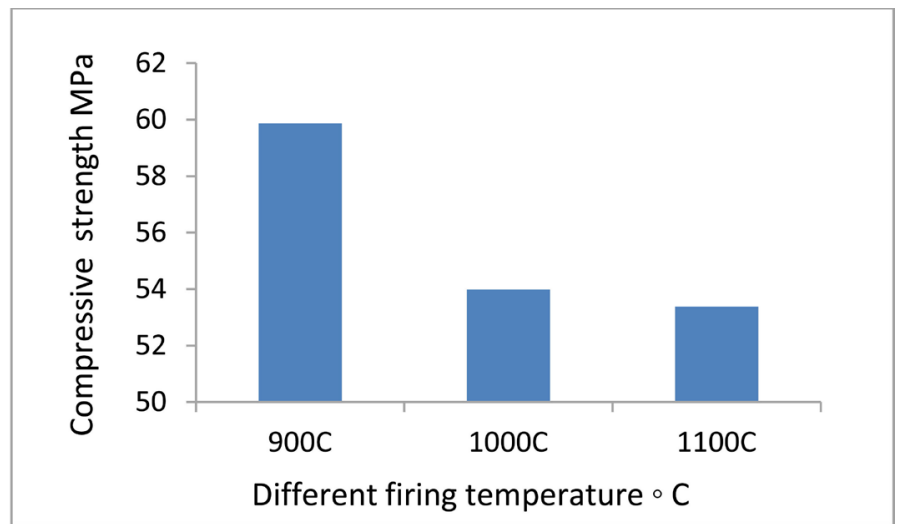

Figure 8. Variation of mechanical strength with temperature for sample-R (red clay).

Figure 8 shows the mechanical strength of the sample-R (red clay). The strength of the ceramic bodies was within the range of $53.38-59.86 \mathrm{MPa}$ which is the range required by ISO 13006 for the manufacture of ceramic tiles [27]. It shows that with increasing temperature, the strength decreased. It might be due to the effect of crystallization with increasing firing temperature [28]. The mechanical behavior of the sample can be explained on consideration of different microstructure during sintering and glass formation acts to densify the structure by liquid phase sintering.

Figure 9 illustrates the images of the surface of the sintered samples, observed by scanning electron microscope (SEM). Ceramic sample sintered at $1000^{\circ} \mathrm{C}$ and $1100^{\circ} \mathrm{C}$ are crystallized, however, sample sintered at $1100^{\circ} \mathrm{C}$ shows well crystallized and large pore space in the sample. The effect of increasing temperatures is the reduction of porosity and the pores join together to form larger pores [7]. Microstructre of the samples correlates with the discussed variation in technological properties as a function of temperature. The optimal vitrification range is achieved when the porosity reaches a minimum value as well as linear shrinkage is a maximum [7], which correlates the Figure 6 and Figure 7. 


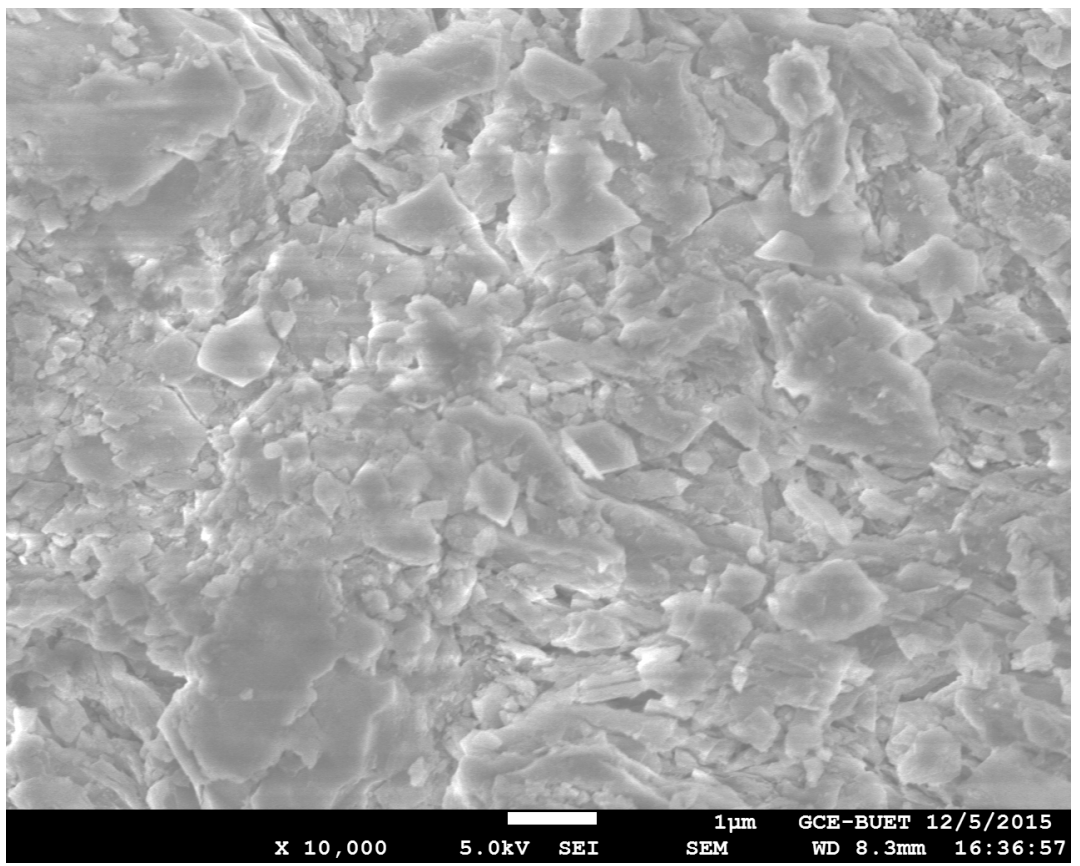

(a)

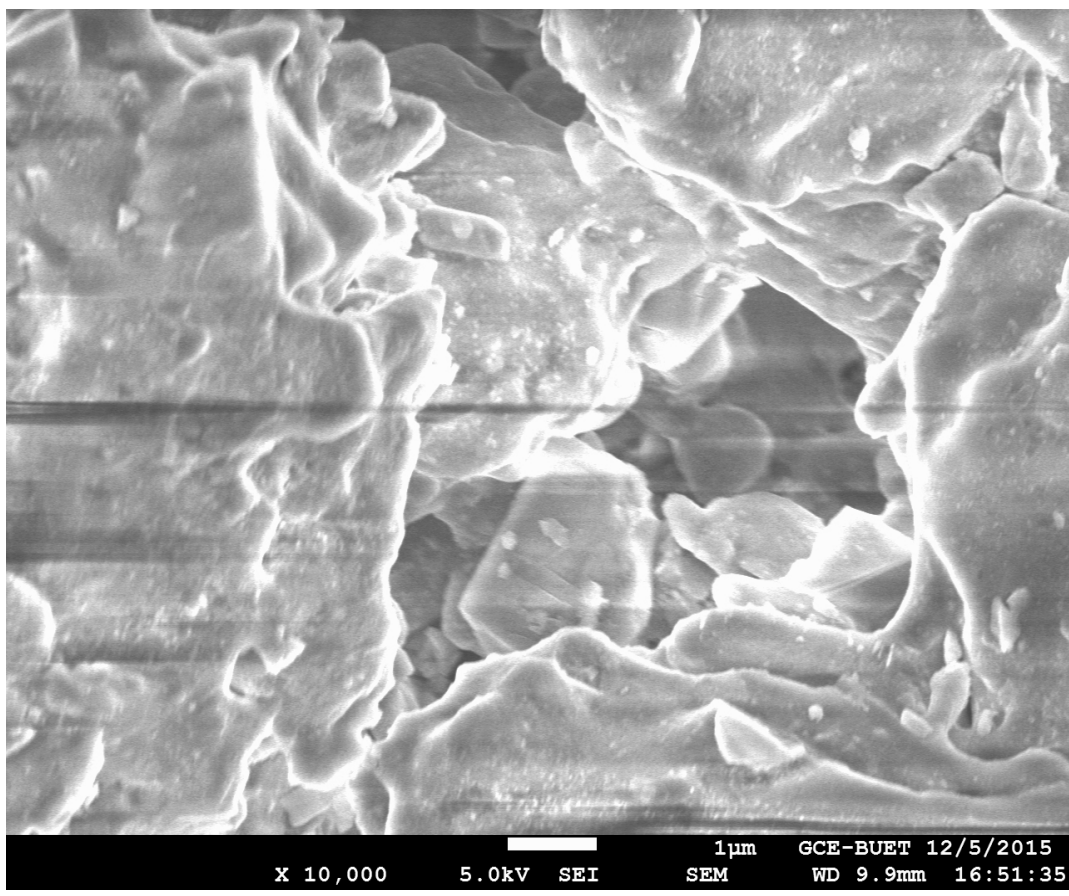

(b)

Figure 9. SEM photograph for sample-R sintered at $1000^{\circ} \mathrm{C}$ (a) and $1100^{\circ} \mathrm{C}(\mathrm{b})$.

The densification behaviour of the Sitakunda red clay is influenced by the sources of flux materials such as $\mathrm{K}_{2} \mathrm{O}, \mathrm{Na}_{2} \mathrm{O}$ and $\mathrm{Fe}_{2} \mathrm{O}_{3}$, which favour the formation of a vitreous phase in $1100^{\circ} \mathrm{C}$ [29]. The increasing maturation achieved at higher temperatures also promotes the incorporation of iron ions in the glassy phase or in the newly formed crystalline phases [30] [31] that might be also affect mechanical strength of the samples. 


\section{Conclusion}

The results obtained in this research show that Sitakunda shale can be used for different ceramic applications. Mineralogical, chemical, particle size and plasticity analyses confirmed the potential suitability of raw materials for ceramic production. These clay deposits could be used to produce a wide range of ceramic product by using advantages of low temperature. Low linear firing shrinkage and water absorption of the developing ceramic bodies were observed which are suitable for the development of ceramic tiles. The water absorption of ceramic product of red sample was within the range from $1.5 \%$ to $6 \%$, which might be used for vitrified ceramic tiles, and water absorption of ceramic product grey sample was within the range from $6 \%$ to $11 \%$, which might be used for porous tiles. Mechanical strength of red deposits of clay was also within the range of standard. The red color product will be superior commercial value comparison with other industrial materials. Therefore, Sitakunda clay deposits of Bangladesh will be suitable source for use as raw materials in making ceramic tiles.

\section{Acknowledgements}

The authorities of Bangladesh Council of Scientific and Industrial Research (BCSIR) are highly acknowledged for providing research grant (R\&D) for this work.

\section{References}

[1] Hajjaji, M., Kacim S. and Boulmane, M. (2002) Mineralogy and Firing Characteristics of a Clay from the Valley of Ourika (Morocco). Applied Clay Science, 21, 203-212. https://doi.org/10.1016/S0169-1317(01)00101-6

[2] Bauluz, B., Mayayo, M.J., Fernández -Nieto, C., Cultrone, G. and González López, J.M. (2003) Assessment of Technological Properties of Calcareous and Non-Calcareous Clays Used for the Brick-Making Industry of Zaragoza (Spain). Applied Clay Science, 2, 121-126. https://doi.org/10.1016/S0169-1317(03)00152-2

[3] Lucas, J. (2003) Azulejos ou Ladrilhos Ceramicos, Descricao Geral, Exigencias Normativas, Classificacao Funcional. LNEC, Lisboa.

[4] Verduch, A.G. (1995) Características de las Arcillas Empleadas en la Fabric ación de Ladrillos. Técnica Cerámica, 232, 214-228.

[5] Fabbri, B. (1994) Quality Assurance of Ceramic Clays-A Deeper Understanding. Schmid, Freiburg, Allemagne.

[6] Mortland, M., Shaobai, S. and Boyd, S. (1986) Clay Organic Complexes as Adsorbants for Phenols and Chlorophenols. Clays and Clay Minerals, 34, 581-585. https://doi.org/10.1346/CCMN.1986.0340512

[7] Baccoura, H., Medhioub, M., Jamoussi, F. and Mhiri, T. (2009) Influence of Firing Temperature on the Ceramic Properties of Triassic Clays from Tunisia. Journal of Materials Processing Technology, 209, 2812-2817. https://doi.org/10.1016/j.jmatprotec.2008.06.055

[8] Mahmood, M.A.A., Rahman, M.S. and Zaman, T. (2013) Ceramics in Bangladesh: Its Recent Evolution and Future Prospect. International Conference of Mechanical, Industrial and Materials Engineering, RUET, Rajshahi, 1-3 November 2013, 
729-732.

[9] Uddin, A. and Lundberg, N. (1998) Unroofing History of the Eastern Himalaya and the Indo-Burman Ranges: Heavy-Mineral Study of Cenozoic Sediments from the Bengal Basin, Bangladesh. Journal of Sedimentary Research, 68, 465-472. https://doi.org/10.2110/jsr.68.465

[10] Alam, M. (1989) Geology and Depositional History of Cenozoic Sediments of the Bengal Basin of Bangladesh. Palaeogeography, Palaeoclimatology, Palaeoecology, 69, 125-139. https://doi.org/10.1016/0031-0182(89)90159-4

[11] Bakhtine, M.I. (1966) Major Tectonic Features of Pakistan, Part-2. Eastern Province Science and Industry, 4, 89-100.

[12] Mominullah, M. (1978) Geology of the Northern Part of Chittagong District, Bangladesh. Records of the Geological Survey of Bangladesh, 22, 18.

[13] Reimann, K.U. (1993) Geology of Bangladesh, Stuttgart. Gebruder-Borntrager, Berlin.

[14] Holtrop, J.F. and Keizer, J. (1970) Some Aspects of the Stratigraphy and Correlation of the Surma Basin Wells, East Pakistan. ECAFE Mineral Resources Development Series, 36, 143-154.

[15] Imam, M.B. and Shaw, H.F. (1987) Diagenetic Controls on the Reservoir Properties of Gas Bearing Neogene Surma Group Sandstones in the Bengal Basin, Bangladesh. Marine and Petroleum Geo, 4, 103-110. https://doi.org/10.1016/0264-8172(87)90026-2

[16] Rahman, M.J.J., Faupl, P. and Alam, M.M. (2009) Depositional Facies of the Subsurface Neogene Surma Group in the Sylhet Trough of the Bengal Basin, Bangladesh: Record of Tidal Sedimentation. International Journal of Earth Sciences, 98, 1971-1980. https://doi.org/10.1007/s00531-008-0347-7

[17] Rahman, M.J.J. and McCann, T. (2012) Diagenetic History of the Surma Group Sandstones (Miocene) in the Surma Basin, Bangladesh. Journal of Asian Earth Sciences, 45, 65-78. https://doi.org/10.1016/j.jseaes.2011.09.019

[18] ASTM, Designation: C 20-00 (2010) Standard Test Methods for Apparent Porosity, Water Absorption, Apparent Specific Gravity and Bulk Density of Burned Refractory Brick and Shapes by Boiling Water.

[19] Costa, F.B., Teixeira, S.R., Souza, A.E. and Santos, G.T.A. (2009) Recycling of Glass Cullet as Aggregate for Clays Used to Produce Roof Tiles. Materia, 14, 1146-1153.

[20] Holtz, R.D. and. Kovacs, W.D. (1981) An Introduction to Geotechnical Engineering. Prentice Hall, Englewood Cliffs.

[21] Dondi, M., Fabbri, B. and Laviano, R. (1992) Characteristics of the Clays Utilized in the Brick Industry in Apulia and Basilicata (Southern Italy). Mineralogica et Petrographica Acta, 35, 181-191.

[22] Ekosse, G.E. and Mulaba, A. (2008) Granulometric Evaluation of Continental Bentonites and Kaolin for Ceramic Applications. Journal of Applied Sciences, 8, 1021-1027. https://doi.org/10.3923/jas.2008.1021.1027

[23] Parras, J., Sanchez, C., Rodas, M. and Luque, F.J. (1996) Ceramic Applications of Middle Ordovician Shales from Central Spain. Applied Clay Science, 11, 25-41. https://doi.org/10.1016/0169-1317(96)00003-8

[24] Imam, M.B. (1989) Clay Minerals in Sandstones from Bhuban and Bokabil Formations: Implications in Petroleum Geology. Bangladesh Journal of Geology, 8, 1-11.

[25] Rahman, M.J.J. and Faupl, P. (2003) The Composition of the Subsurface Neogene Shales of the Surma Group from the Sylhet Trough, Bengal Basin, Bangladesh. In: 
Alam, M.M. and Curray, J.R., Eds., Sedimentary Geology of the Bengal Basin, Bangladesh, in Relation to the Asia-Greater India Collision and the Evolution of the Eastern Bay of Bengal, Sedimentary Geology, Elsevier Science, Amsterdam, 155/3-4, 407-417.

[26] Dondi, M., Raimondo, M. and Zanelli, C. (2014) Clays and Bodies for Ceramic Tiles: Reappraisal and Technological Classification. Applied Clay Science, 96, 91-109. https://doi.org/10.1016/j.clay.2014.01.013

[27] Junkes, J.A., Carvalho, M.A., Segadães, A.M. and Hotza, D. (2011) Ceramic Tile Formulations from Industrial Waste. Interceram, 60, 36-41.

[28] Aramide, F.O. (2015) Effects of Sintering Temperature on the Phase Developments and Mechanical Properties Ifon Clay. Leonardo Journal of Sciences, 26, 67-82.

[29] Kamseu, E., Leonelli, C., Boccaccini, D.N., Veronesi, P., Miselli, P. and Pellacani, G. (2007) Characterisation of Porcelain Compositions using Two China Clays from Cameroon. Ceramics International, 33, 851-857. https://doi.org/10.1016/j.ceramint.2006.01.025

[30] Ferrari, S. and Gualtieri, A.F. (2006) The Use of Illitic Clays in the Production of Stoneware Tile Ceramics. Applied Clay Science, 32, 73-81.

[31] Schneider, H. and Rager, H. (1986) Iron Incorporation in Mullite. Ceramics International, 12, 117-125. https://doi.org/10.1016/0272-8842(86)90034-9 